\title{
Experimental determination of monoethanolamine protonation constant and its temperature dependency
}

\author{
Sholeh Ma'mun*, Kamariah, Sukirman, Desi Kurniawan, Eleonora Amelia, Vitro Rahmat, and Deasy R. Alwani \\ Department of Chemical Engineering Faculty of Industrial Technology Islamic University of Indonesia, 55501 Yogyakarta, \\ Indonesia
}

\begin{abstract}
Carbon dioxide as one of the major contributors to the global warming problem is produced in large quantities by many important industries and its emission seems to rise from year to year. Aminebased absorption is one of the methods to capture $\mathrm{CO}_{2}$ from its sources. As a reactive system, mass transfer and chemical reaction take place simultaneously. In a vapor-liquid equilibrium model for the $\mathrm{CO}_{2}$ amine-water system, some parameters such as mass transfer coefficients and chemical equilibrium constants need to be known. However, some parameters could be determined experimentally and the rests could be regressed from the model. The protonation constant $\left(\mathrm{pK}_{\mathrm{a}}\right)$, as one of the model parameters, could then be measured experimentally. The purpose of this study is to measure the $\mathrm{pK}_{\mathrm{a}}$ of monoethanolamine (MEA) at a range of temperatures from 303 to $330 \mathrm{~K}$ by a potentiometric titration method. The experimental data obtained were in a good agreement with the literature data. The $\mathrm{pK}_{\mathrm{a}}$ data from this work together with those from the literature were then correlated in an empirical correlation to be used for future research.
\end{abstract}

\section{Introduction}

Carbon dioxide $\left(\mathrm{CO}_{2}\right)$ is known as one of the major contributors to the global warming problem. Carbon dioxide is produced in large quantities from coal-fired power plants, steel production, petrochemical manufacturing, cement production, and natural gas purification as well as the exhaust gas from the transportation sectors. In the past decades, $\mathrm{CO}_{2}$ recovery from flue gas streams was conducted mainly for Enhanced Oil Recovery (EOR) operations. Moreover, $\mathrm{CO}_{2}$ was also produced for other industrial applications such as carbonation of brine, welding as an inert gas, food and beverage carbonation, dry ice, urea production, and soda ash industry $[1,2]$. However, environmental concerns such as the global climate change are now focused as one of the most important and challenging environmental issues facing the world community and drive an intensive research on $\mathrm{CO}_{2}$ capture and sequestration [3].The $\mathrm{CO}_{2}$ emission seems to rise from year to year. In 2005, 26.3 Gt of $\mathrm{CO}_{2}$ was emitted globally and reached $32 \mathrm{Gt}$ in 2010 [4]. Necessary efforts to reduce the $\mathrm{CO}_{2}$ emission are, therefore, required. Absorption is one of the methods to capture $\mathrm{CO}_{2}$ from its emission sources.

A commercial absorbent for $\mathrm{CO}_{2}$ removal requires both a high net cyclic capacity and high reaction rate for $\mathrm{CO}_{2}$ as well as high chemical stability. In addition, other criteria that need to be considered are, according to [5], base strength $\left(\mathrm{pK}_{\mathrm{a}}\right)$, molecular weight per $\mathrm{NH}$ functionality, slope of equilibrium curve, heat of absorption, viscosity, nature of degradation products, nitrosamine formation potential, cost and availability, and HSE (Health, Safety, and Environment). Research on solvent development has been conducted to meet those criteria by testing alkanolamines and their blends, sodium carbonate solutions, chilled ammonia, and amino acid salts [3, 6-13].

Aqueous solutions of alkanolamines are the most commonly used as chemical absorbents for the $\mathrm{CO}_{2}$, such as $\mathrm{CO}_{2}$ removal from natural gas, from refinery and synthesis gas streams. Among them, aqueous monoethanolamine $\left(\mathrm{H}_{2} \mathrm{NCH}_{2} \mathrm{CH}_{2} \mathrm{OH}\right.$, MEA) as a primary amine has been used extensively for this purpose. Fig. 1 shows the MEA structure. It has several advantages over other commercial alkanolamines, such as high reactivity, low solvent cost, low molecular weight and, thus, high absorbing capacity on a mass basis and reasonable thermal stability and thermal degradation rate. However, MEA has some drawbacks such as high enthalpy of reaction with $\mathrm{CO}_{2}$ leading to higher regeneration energy consumption in desorber, formation of a stable carbamate and also formation of degradation products with COS or oxygen bearinggases, inability to remove mercaptans, vaporization losses because of relatively high vapor pressure [14, 15], more corrosive than many other alkanolamines $[15,16]$ and non-selective for the removal of $\mathrm{H}_{2} \mathrm{~S}$ in the presence of $\mathrm{CO}_{2}$ [14].<smiles>NCCO</smiles>

Fig 1. Structure of MEA molecule 
The objective of this study is to evaluate the protonation constant $\left(\mathrm{pK}_{\mathrm{a}}\right)$ of MEA at a range of temperatures from 303 to $333 \mathrm{~K}$ using a potentiometric titration method.

\section{Theory}

Carbon dioxide capture using amine-based absorption is categorized as a chemical absorption process where mass transfer and chemical reaction occur simultaneously. A series of physical and chemical reaction equilibria for the $\mathrm{CO}_{2}-\mathrm{amine}-\mathrm{H}_{2} \mathrm{O}$ system can, according to [17], be written as follows:

$$
\begin{gathered}
\mathrm{CO}_{2(\mathrm{~g})} \leftrightarrow \mathrm{CO}_{2(\mathrm{l})} \\
2 \mathrm{H}_{2} \mathrm{O} \leftrightarrow \mathrm{H}_{3} \mathrm{O}^{+}+\mathrm{OH}^{-} \\
\mathrm{CO}_{2(\mathrm{l})}+2 \mathrm{H}_{2} \mathrm{O} \leftrightarrow \mathrm{HCO}_{3}^{-}+\mathrm{H}_{3} \mathrm{O}^{+} \\
\mathrm{HCO}_{3}^{-}+\mathrm{H}_{2} \mathrm{O} \leftrightarrow \mathrm{CO}_{3}^{=}+\mathrm{H}_{3} \mathrm{O}^{+} \\
\mathrm{AmH}^{+}+\mathrm{H}_{2} \mathrm{O} \leftrightarrow \mathrm{Am}+\mathrm{H}_{3} \mathrm{O}^{+} \\
\mathrm{Am}+\mathrm{CO}_{2(\mathrm{l})}+\mathrm{H}_{2} \mathrm{O} \leftrightarrow \mathrm{AmCOO}^{-}+\mathrm{H}_{3} \mathrm{O}^{+} \\
{ }^{+} \mathrm{HAmCOO}^{-}+\mathrm{H}_{2} \mathrm{O} \leftrightarrow \mathrm{AmCOO}^{-}+\mathrm{H}_{3} \mathrm{O}^{+}
\end{gathered}
$$

where g, 1, and Am refer to gas, liquid, and amine molecule, respectively.

From (1) to (7), the chemical equilibrium constants as a function of the activity coefficients $\gamma_{i}$ and mole fraction $x_{\mathrm{i}}$ can be formulated as follows

$$
K_{j}=\prod_{i} a_{i}^{v_{i j}}=\prod_{i}\left(\gamma_{i} x_{i}\right)^{v_{i j}} j=1,2, \ldots, R
$$

where $v_{\mathrm{ij}}$ is the stoichiometric coefficient for component $i$ in reaction $j$ and $\mathrm{R}$ is the number of chemical reactions.

The equilibrium constant in (5) is the protonation constant $\left(\mathrm{K}_{\mathrm{a}}\right)$ of amine in which its value can be experimentally measured.

The protonation constant, also known as the acid dissociation constant, can be calculated from the reaction of a weak acid and a strong base where $\mathrm{K}_{\mathrm{a}}$ value is equal to the concentration of $\mathrm{H}^{+}$ions in the solution. This occurs when the total volume of titrant added is equal to half of the equivalence volume $\left(\mathrm{V}_{\mathrm{e}}\right)$ required.

Let a weak acid HA react with a strong base $\mathrm{BOH}$ in solution

$$
\mathrm{HA}+\mathrm{BOH} \leftrightarrow \mathrm{BA}+\mathrm{H}_{2} \mathrm{O}
$$

in which the remaining weak acid HA and the salt formed BA dissociate in the solution. Since HA is a weak acid with small $\mathrm{K}_{\mathrm{a}}$ value, the amount of HA in the solution is, therefore, assumed to be constant. The number of $\mathrm{A}$ - ions in the solution are mostly from BA dissociation, i.e. A ions from HA dissociation is negligible. In this condition, the weak acid HA concentration in the solution is equal to the concentration of $\mathrm{A}$ - ions, so that the protonation constant $\left(\mathrm{K}_{\mathrm{a}}\right)$ can be expressed as follows

$$
\mathrm{K}_{\mathrm{a}}=\frac{\left[\mathrm{H}^{+}\right]\left[\mathrm{A}^{-}\right]_{\text {total }}}{[\mathrm{HA}]_{\text {left }}} \approx\left[\mathrm{H}^{+}\right]
$$

Equation (10) indicates that the $K_{a}$ value of the weak acid HA approximately is equal to the concentration of $\mathrm{H}^{+}$ions or, in other words, the $\mathrm{pK}_{\mathrm{a}}$ equals the $\mathrm{pH}$ of the solution.

The temperature dependency of the protonation constant $\left(\mathrm{K}_{\mathrm{a}}\right)$ can, according to [18], be expressed in the form

$$
\ln \mathrm{K}_{\mathrm{a}}=\mathrm{A}+\frac{\mathrm{B}}{\mathrm{T}}+\mathrm{C} \ln \mathrm{T}+\mathrm{DT}+\mathrm{ET}^{2}
$$

where $\mathrm{T}$ is the temperature in $\mathrm{K}$, while $\mathrm{A}, \mathrm{B}, \mathrm{C}, \mathrm{D}$ and $\mathrm{E}$ are the coefficients that can be determined by use of the regression method which gives the Sum of the Squared Errors (SSE) minimum. The minimization of errors will produce linear systems expressed mathematically as

$$
\begin{array}{r}
\sum \ln \mathrm{K}_{\mathrm{a}}=\mathrm{nA}+\mathrm{B} \sum \frac{1}{\mathrm{~T}}+\mathrm{C} \sum \ln \mathrm{T}+\mathrm{D} \sum \mathrm{T}+\mathrm{E} \sum \mathrm{T}^{2} \\
\sum \frac{\ln \mathrm{K}_{\mathrm{a}}}{\mathrm{T}}=\mathrm{A} \sum \frac{1}{\mathrm{~T}}+\mathrm{B} \sum \frac{1}{\mathrm{~T}^{2}}+\mathrm{C} \sum \frac{\ln \mathrm{T}}{\mathrm{T}}+\mathrm{D}+\mathrm{E} \sum \mathrm{T}
\end{array}
$$

$$
\begin{array}{r}
\sum\left(\ln \mathrm{T} \ln \mathrm{K}_{\mathrm{a}}\right)=\mathrm{A} \sum \ln \mathrm{T}+\mathrm{B} \frac{\ln \mathrm{T}}{\mathrm{T}}+\mathrm{C} \sum(\ln \mathrm{T})^{2}+ \\
\mathrm{D} \sum(\mathrm{T} \ln \mathrm{T})+\mathrm{E} \sum\left(\mathrm{T}^{2} \ln \mathrm{T}\right)
\end{array}
$$

$$
\begin{gathered}
\sum\left(\mathrm{T} \ln \mathrm{K}_{\mathrm{a}}\right)=\mathrm{A} \sum \mathrm{T}+\mathrm{B}+\mathrm{C} \sum(\mathrm{T} \ln \mathrm{T})+\mathrm{D} \sum \mathrm{T}^{2}+ \\
\mathrm{E} \sum \mathrm{T}^{3}
\end{gathered}
$$

$$
\begin{gathered}
\sum\left(\mathrm{T}^{2} \ln \mathrm{K}_{\mathrm{a}}\right)=\mathrm{A} \sum \mathrm{T}^{2}+\mathrm{B} \sum \mathrm{T}+\mathrm{C} \sum\left(\mathrm{T}^{2} \ln \mathrm{T}\right)+ \\
\mathrm{D} \sum \mathrm{T}^{3}+\mathrm{E} \sum \mathrm{T}^{4}
\end{gathered}
$$

where $n$ is the number of data. From (12) to (16), it is obtained a set of linear equations. Some methods can be applied to solve the linear equation systems, e.g. the Gauss elimination method [19]. This solution method will then be used in this work.

\section{Materials and method}

\subsection{Materials}

The materials used in this work consist of monoethanolamine (MEA) obtained from SigmaAldrich with purity of min. $98 \%$, sulfuric acid $\left(\mathrm{H}_{2} \mathrm{SO}_{4}\right)$ from Merck with purity of $96.0 \%$, and distilled water. Moreover, MEA received from the manufacturer was used directly without further purification.

\subsection{Apparatus and procedure}

Figure 2 shows the experimental setup consisting of a 300-mL jacketed reactor, a pH meter (Lutron PH-201 with $\mathrm{pH}$ electrode PE-03 and accuracy up to 0.01 ), a $\mathrm{TFA}^{\circledR}$ digital thermometer with accuracy up to $0.1^{\circ} \mathrm{C}$, a 
memmert water bath, an OHAUS ${ }^{\circledR}$ digital balance with readability up to $0.0001 \mathrm{~g}$, a magnetic stirrer, and a 5$\mathrm{mL}$ syringe.

A certain amount of MEA min. 98\%, $0.5 \mathrm{~g}$, was added into a beaker glass containing $\sim 50 \mathrm{~mL}$ of distilled water. The solution was then stirred some time to make it homogeneous. A certain amount of titrant, i.e. $0.1 \mathrm{M}$ $\mathrm{H}_{2} \mathrm{SO}_{4}$ solution, in a syringe was added into the beaker glass. The reaction taken place was exothermic, so that the solution temperature was slightly increased. It took some time until the temperature and $\mathrm{pH}$ of the solution stable. The addition of $0.1 \mathrm{M} \mathrm{H}_{2} \mathrm{SO}_{4}$ from the syringe was repeated until the equivalence point is reached. When the titration was about the equivalence point, the titrant must be added with a very small amount, i.e. $\sim 0.02 \mathrm{~mL}$, to ensure that the $\mathrm{pH}$ did not change much, so that the equivalence point was not exceeded.

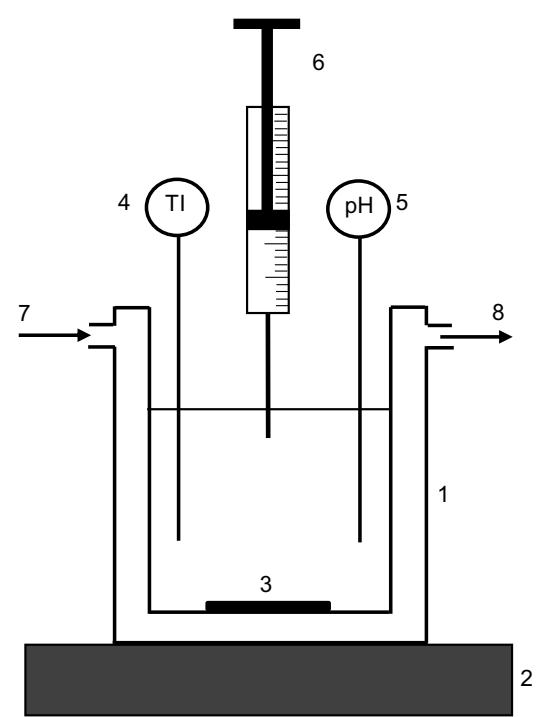

Fig 2. Experimental setup for $\mathrm{pK}_{\mathrm{a}}$ measurements (1: jacketed reactor, 2: magnetic stirrer, 3: stirrer, 4: thermometer, 5: $\mathrm{pH}$ meter, 6: syringe, 7 : heating medium inlet, 8 : heating medium outlet)

\section{Results and discussion}

The $\mathrm{pK}_{\mathrm{a}}$ measurements of MEA were conducted at a range of temperatures from 303 to $333 \mathrm{~K}$ using the potentiometric titration method with $0.1 \quad \mathrm{M} \mathrm{H}_{2} \mathrm{SO}_{4}$ solution as the titrant.

As seen in Fig. 2, the titrant was discretely added. The amount of titrant added was calculated from the syringe weight difference. The titration was terminated after the solution reached $\mathrm{pH} \sim 2.0$, i.e. excess of $\mathrm{H}_{2} \mathrm{SO}_{4}$. This is to ensure that all MEA molecules have reacted with $\mathrm{H}_{2} \mathrm{SO}_{4}$.

From the titration curve obtained, the $\mathrm{pK}_{\mathrm{a}}$ value can then be determined graphically. Figure 3 shows the titration curve for Run 1 in which the equivalence point was reached when the titrant volume $\left(\mathrm{V}_{\mathrm{e}}\right)$ added was $\sim 45 \mathrm{~mL}$. It was quite challenging to determine the precise equivalence point directly from the curve. Another step is therefore required, i.e. determination of
$\mathrm{pH}$ slope $(\Delta \mathrm{pH} / \Delta \mathrm{V})$ for every single point, as seen in Fig. 4. The equivalence point is reached when the slope $(\Delta \mathrm{pH} / \Delta \mathrm{V})$ gives minimum value. However, the precise equivalence point cannot still be read from the figure; therefore enlarging the figure scale around the equivalence point is required. It can be seen from Fig. 5 that the equivalence volume $\left(\mathrm{V}_{\mathrm{e}}\right)$ for Run 1 is 45.007 $\mathrm{mL}$.

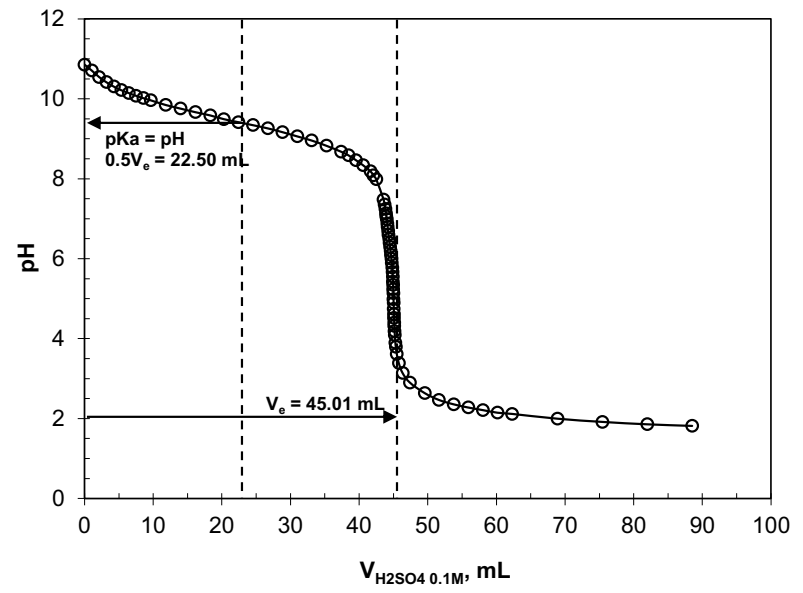

Fig 3. Titration curve of MEA at $303 \mathrm{~K}\left(\mathrm{~V}_{\mathrm{e}}=\right.$ the volume of titrant at the equivalence point)

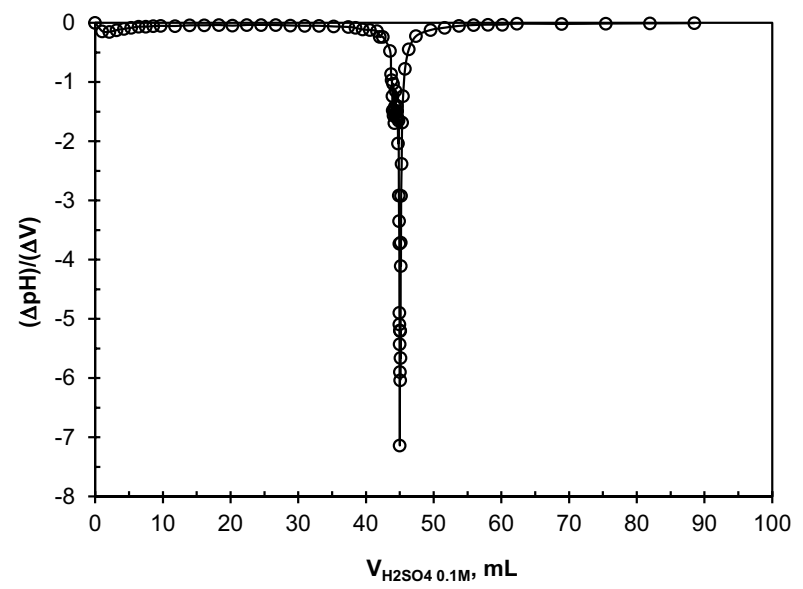

Fig 4. Titration slope $(\Delta \mathrm{pH} / \Delta \mathrm{V})$ of MEA at $303 \mathrm{~K}$

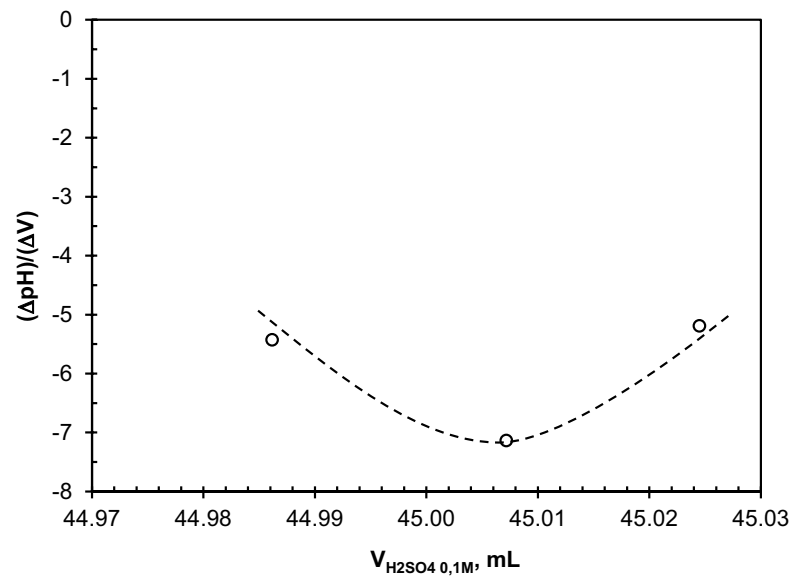

Fig 5. Titration slope $(\Delta \mathrm{pH} / \Delta \mathrm{V})$ around the equivalence point at $303 \mathrm{~K}$ 
Furthermore, the $\mathrm{pK}_{\mathrm{a}}$ value occurs when the titrant volume equals half of the equivalence volume. At this point, $\mathrm{pK}_{\mathrm{a}}$ is equal to $\mathrm{pH}$. It can be seen from Fig. 3 that $\mathrm{pK}_{\mathrm{a}}$ is 9.41 . Similar procedure was applied to the other data and the results are then summarized in Table 1.

Table 1. pKa values at various temperature

\begin{tabular}{|c|c|c|c|c|}
\hline Run & $\mathbf{T , ~ K}$ & $\begin{array}{c}\text { Number of } \\
\text { data }\end{array}$ & $\mathbf{p K _ { \mathbf { a } }}$ & $\mathbf{p K}_{\mathbf{a}-\text { average }}$ \\
\hline 1 & 303 & 79 & 9.41 & 9.43 \\
2 & 303 & 85 & 9.44 & \\
3 & 313 & 76 & 9.18 & 9.14 \\
4 & 313 & 86 & 9.10 & \\
5 & 323 & 89 & 8.88 & 8.90 \\
6 & 323 & 82 & 8.91 & \\
7 & 333 & 87 & 8.68 & 8.67 \\
8 & 333 & 85 & 8.66 & \\
\hline
\end{tabular}

Table 2. Comparison of experimental data with those obtained from literature

\begin{tabular}{|l|c|c|c|c|c|c|c|}
\hline \multirow{2}{*}{$\mathbf{T}, \mathbf{K}$} & \multicolumn{7}{|c|}{$-\ln \mathbf{K}_{\mathbf{a}}$} \\
\cline { 2 - 7 } & {$[20]$} & {$[21]$} & {$[22]$} & {$[23]$} & {$[24]$} & {$[25]$} & $\begin{array}{c}\text { This } \\
\text { work }\end{array}$ \\
\hline 273 & 23.73 & & & & & & \\
278 & 23.33 & & & & & & \\
283 & 22.95 & & & & & & \\
288 & 22.57 & 22.57 & & & & 22.25 & \\
293 & 22.21 & & & 22.08 & & & \\
298 & 21.87 & 21.88 & 21.90 & 21.74 & 21.85 & 21.72 & \\
303 & 21.53 & & & 21.42 & & & 21.71 \\
308 & 21.20 & 21.20 & & 21.10 & & 21.20 & \\
313 & 20.88 & & & 20.80 & 20.84 & & 21.05 \\
318 & 20.59 & 20.56 & & 20.50 & & 20.64 & \\
323 & 20.29 & & & 20.21 & 20.25 & & 21.49 \\
333 & & & & & 19.71 & & 19.96 \\
343 & & & & & 19.08 & & \\
353 & & & & & 18.55 & & \\
363 & & & & & 18.18 & & \\
\hline
\end{tabular}

The $\mathrm{pK}_{\mathrm{a}}$ values of MEA obtained from this work are then compared to those obtained from the literature as given di Table 2 and Fig. 6 . It can be seen from Fig. 6 that the results, in general, agree well with the literature data, except at $333 \mathrm{~K}$, where the $\ln \mathrm{K}_{\mathrm{a}}$ from this study is a bit lower compared to that from [24]. Even though the vapor pressure of MEA at $333 \mathrm{~K}$ is relatively low $\left(\mathrm{P}^{\circ}=\right.$ $0.66 \mathrm{kPa}[26]$ ), the evaporation loss during titration might slightly reduce the amount of MEA in the solution, thereby slightly affecting the measurement result.

There are 38 data points of $\mathrm{K}_{\mathrm{a}}$ obtained from this work together with the data from the literature as seen in Table 2. By use of the linear regression method, the protonation constant $\mathrm{K}_{\mathrm{a}}$ can then be correlated as a function of temperature in an empirical equation form as follows:

$$
\begin{gathered}
\ln \mathrm{K}_{\mathrm{a}}=-164.40+\frac{4.36 \times 10^{-4}}{\mathrm{~T}}+25.50 \ln \mathrm{T}+ \\
1.37 \times 10^{-8} \mathrm{~T}+3.11 \times 10^{-5} \mathrm{~T}^{2}
\end{gathered}
$$

Equation (17) could be useful to determine the protonation constant with its temperature dependency for future work.

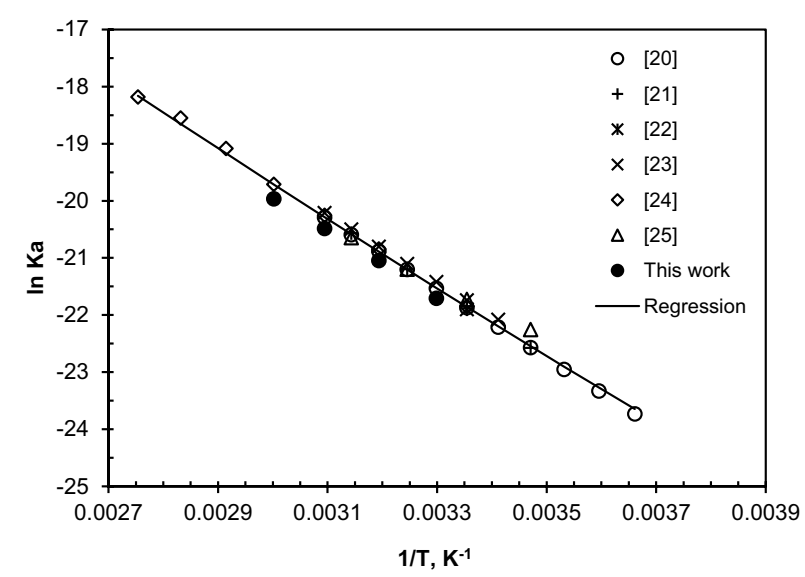

Fig 6. Comparison of the measured $\mathrm{K}_{\mathrm{a}}$ of MEA with those obtained from literature [20-25]

\section{Conclusion}

The protonation constant $\left(\mathrm{pK}_{\mathrm{a}}\right)$ measurements of MEA were conducted at a range of temperatures from 303 to $330 \mathrm{~K}$ by a potentiometric titration method to complement the existing data in the literature. The experimental $\mathrm{pK}_{\mathrm{a}}$ data obtained in this work, in general, agree well with the results published in the literature. The $\mathrm{pK}_{\mathrm{a}}$ data from this work together with those from the literature were then correlated in an empirical form to easily be used for future research.

The authors acknowledge the Islamic University of Indonesia for the financial support through the Department of Chemical Engineering Research Grant 2016.

\section{References}

1. A.B. Rao, E.S. Rubin. A, Environ. Sci. Technol. 36, 4467 (2002)

2. T. Suda, M. Iijima, H. Tanaka, S. Mitsuoka, T. Iwaki, Environ. Prog. 16, 200 (1997)

3. S. Ma'mun, H.F. Svendsen, K.A. Hoff, O. Juliussen, Energy Convers. Manage. 48, 251 (2007)

4. Van der Hoeven, World Energy Outlook 2012 (International Energy Agency, Paris, France, 2012)

5. K.A. Hoff, E.F. da Silva, I. Kim, A. Grimstvedt, S. Ma'mun, Energy Procedia 37, 292 (2013)

6. S. Ma'mun, R. Nilsen, H.F. Svendsen, J. Chem. Eng. Data 50, 630 (2005)

7. S. Ma'mun, V.Y. Dindore, H.F. Svendsen, Ind. Eng. Chem. Res. 46, 385 (2007) 
8. R. Idem, M. Wilson, P. Tontiwachwuthikul, A Chakma, A. Veawab, A. Aroonwilas, D. Gelowitz, Ind. Eng. Chem. Res. 45, 2414 (2006)

9. Y. Lu, X. Ye, Z. Zhang, A. Khodayari, T. Djukadi, Energy Procedia 4, 1286 (2011)

10. Alstom, Chilled ammonia-based wet scrubbing for post-combustion $\mathrm{CO}_{2}$ capture (DOE/NETL report No. 401/021507, 2007)

11. H. Knuutila, U.E. Aronu, H.M. Kvamsdal, A. Chikukwa, Energy Procedia 4, 1550 (2011)

12. S. Ma'mun, I. Kim, Energy Procedia 37, 331 (2013)

13. S. Ma'mun, Energy Procedia 51, 191 (2014)

14. F.-Y. Jou, A.E. Mather, F.D. Otto, Can. J. Chem. Eng. 73, 140 (1995)

15. Y. Liu, L. Zhang, S. Watanasiri, Ind. Eng. Chem. Res. 38, 2080 (1999)

16. R.W. Bucklin, Oil Gas J. 204 (1982)

17. S. Ma'mun, J.P. Jakobsen, H.F. Svendsen, O. Juliussen, Ind. Eng. Chem. Res. 45, 2505 (2006)
18. R.H. Weiland, T. Chakravarty, A.E. Mather, Ind. Eng. Chem. Res. 32, 1419 (1993)

19. E. Kreyszig, Advanced engineering mathematics, $10^{\text {th }}$ ed. (John Wiley \& Sons, Inc., USA, 2011)

20. R.G. Bates, G.D. Pinching, J. Res. Natl. Bur. Stand. 46, 349 (1951)

21. S.P. Datta, A.K. Grzybowski, J. Chem. Soc. 3068 (1962)

22. J.-H. Kim, C. Dobrogowska, L.G. Hepler, Can. J. Chem. 65, 1726 (1987)

23. E.S. Hamborg, G.F. Versteeg, J. Chem. Eng. Data 54, 1318 (2009)

24. Kim, C.M. Jens, A. Grimstvedt, H.F. Svendsen, J. Chem. Thermodynamics 43, 1754 (2011)

25. D. Fernandes, W. Conway, X. Wang, R. Burns, G. Lawrance, M. Maeder, G. Puxty, J. Chem. Thermodynamics 51, 97 (2012)

26. R.K. Sinnot, Coulson \& Richardson's Chemical Engineering Volume 6 - Chemical Engineering Design, $4^{\text {th }} \mathrm{ed}$. (Elsevier Butterworth-Heinemann, Oxford, UK, 2005) 